\title{
Pilot-scale study of a structured bed reactor for nitrogen and organic matter removal from sanitary sewage: advances and design challenges
}

\author{
Remoção de nitrogênio e matéria orgânica de esgoto sanitário em reator de leito fixo estruturado \\ em escala piloto: avanços e desafios associados ao aumento de escala \\ Remoción de nitrógeno y la materia orgánica de aguas residuales domésticas en reactor de lecho \\ estructurado a escala piloto: avances y desafíos asociados con la ampliación
}

Received: 10/08/2021 | Reviewed: 10/15/2021 | Accept: 10/20/2021| Published: 10/22/2021

Kiemi de Brito Murata
ORCID: https://orcid.org/0000-0001-5450-3170
School of Administration, Marketing and Communication, Brazil
E-mail: kiemimurata@gmail.com
Bruno Garcia Silva
ORCID: https://orcid.org/0000-0002-9870-2523
University of São Paulo, Brazil
E-mail: b.garciasilva@gmail.com
Carla Eloísa Diniz dos Santos
ORCID: https://orcid.org/0000-0002-5954-1026
Federal University of Triângulo Mineiro, Brazil
E-mail: carla.santos@uftm.edu.br
Dagoberto Yukio Okada
ORCID: https://orcid.org/0000-0003-1859-9851
University of Campinas, Brazil
E-mail: dagokada@ft.unicamp.br
Rafael Brito de Moura
ORCID: https://orcid.org/0000-0002-0273-5663
Federal University of Alfenas, Brazil
E-mail: rafael.moura@unifal-mg.edu.br
Eugenio Foresti
rofidis
ORCID: https://orcid.org/0000-0002-7097-8990
University of São Paulo, Brazil
E-mail: eforesti@sc.usp.br
ORCID: https://orcid.org/0000-0001-7738-3722
University of São Paulo, Brazil
E-mail: mdamianovic@sc.usp.br

\begin{abstract}
Simultaneous nitrification and denitrification (SND) is a process that can remove both nitrogen and organic matter in a single unit. Several bench-scale studies show that the structured bed reactors (STBR) subjected to recirculation and intermittent aeration have achieved a good performance for SND treating different types of wastewater. Thus, this study took a step forward and evaluated the efficiency and stability of treating domestic sewage in a pilot-scale STBR. COD removal efficiencies higher than $87 \%$ were achieved in the whole experimental period. The highest Total-N removal efficiency was approximately $74 \pm 7 \%$ by adopting a hydraulic retention time (HRT) of $47.2 \mathrm{~h}$ and intermittent aeration ( $2 \mathrm{~h}$ aerated and $1 \mathrm{~h}$ non-aerated). The setup of the aeration system was an important mechanism to ensure the optimal balance between nitrification and denitrification in a pilot-scale system.
\end{abstract}

Keywords: Simultaneous nitrification and denitrification; Polyurethane foam; Aeration setup; Isolated communities.

\section{Resumo}

A remoção concomitante de matéria orgânica e nitrogênio em uma única unidade pode ser obtida a partir do processo de nitrificação e desnitrificação simultânea (SND). Diversos trabalhos em escala laboratorial mostram que os reatores de leito estruturado (STBR) submetidos à recirculação e aeração intermitente têm atingido desempenho satisfatório no tratamento de diversos tipos de águas residuárias, via processo SND. Desta forma, este trabalho teve como principal objetivo avaliar a eficiência e estabilidade do processo SND para o tratamento de esgoto doméstico em reator STBR em escala piloto. Eficiências de remoção de DQO superiores a $87 \%$ foram observadas ao longo de todo o período experimental. A máxima eficiência de remoção de $\mathrm{N}$-total foi de, aproximadamente, $74 \pm 7 \%$, com tempo de detenção hidráulica (TDH) de $47.2 \mathrm{~h}$ e ciclo de aeração intermitente de $2 \mathrm{~h}$ com aeração ligada e $1 \mathrm{~h}$ sem aeração. A configuração 
do sistema de aeração se mostrou como um mecanismo fundamental para garantir o equilíbrio na ocorrência dos processos de nitrificação e desnitrificação na unidade piloto.

Palavras-chave: Nitrificação e desnitrificação simultânea; Espuma de poliuretano; Sistema de aeração; Comunidades isoladas.

\section{Resumen}

El proceso de nitrificación y desnitrificación simultánea (SND) permite alcanzar la eliminación combinada de nitrógeno e de la materia orgánica en una sola unidad. Varios estudios en escala de banco muestran que los reactores de lecho estructurado (STBR) con recirculación y aireación intermitente han logrado un buen desempeño para NDS, tratando diferentes tipos de aguas residuales. El propósito de este estudio fue evaluar la eficiencia y estabilidad del STBR a escala piloto tratando aguas residuales domésticas. Se lograron eficiencias de remoción de DQO superiores al $87 \%$ a lo largo del experimento. La mejor eficiencia de remoción de N-total fue aproximadamente $74 \pm 7 \%$, con un tiempo de retención hidráulica (HRT) de 47.2 h y aireación intermitente ( $2 \mathrm{~h}$ airadas y 1 h no airada). La configuración del sistema de aireación fue un mecanismo importante para garantizar el equilibrio óptimo entre la nitrificación y la desnitrificación en un sistema a escala piloto.

Palabras clave: Nitrificación y desnitrificación simultánea; Espuma de poliuretano; Configuración de aireación; Comunidades aisladas.

\section{Introduction}

Basic sanitation universalization poses as a challenge in developing countries such as Brazil. According to the SNIS (Brazilian Sanitation Information System), in 2018, 60.9\% of the urban domestic sewage produced in Brazil was collected and only $46.3 \%$ of the generated sewage received some type of treatment (Sistema Nacional de Informações sobre Saneamento, 2019). Usually, the sewage fraction that is conducted to treatment is centrally treated in complex wastewater treatment plants (WWTPs). In Brazilian isolated communities and rural areas, access to basic sanitation infrastructure is almost non-existent. In these areas, the options adopted are decentralized systems which comprise the collection, treatment, and disposal or reuse of wastewater from individual houses, clusters, rural communities, isolated commercial, industrial, and agricultural facilities or places located near the waste generation (Gikas \& Tchobanoglous, 2009). The decision-making should consider that few will pay the costs of implementing/maintaining such decentralized treatment systems. Therefore, these units demand simplicity in the construction, operation, and waste management to become feasible. Unfortunately, the common options for sewage management adopted are improperly constructed cesspits and final disposal in water bodies and/or soil (IBGE, 2015).

Among the technologies recommended in the literature for the decentralized treatment of sanitary sewage the following can be listed: upflow anaerobic sludge-bed (UASB) reactors, septic tanks, anaerobic pond systems, trickling filters, and constructed wetlands (Moussavi et al., 2010; Santiago-Díaz et al., 2019; Singh et al., 2015). These treatment configurations remove the organic matter while nutrient compounds are slightly removed by other specific alternatives. The control of nutrient discharge should be addressed because of the eutrophication caused by phosphate and nitrogen. According to a report summarized by von Sperling (2016) that is based on data from a survey performed by ANA (Brazillian Water and Basic Sanitation Agency), the main destination of discharged effluent in Brazil is freshwater bodies. This report also pointed out that $64 \%$ of the discharges occurred in critical basins which includes basins in the semiarid region (Brazilian Northeast), basins with low dilution capacity and others with high-polluted streams (von Sperling, 2016). Thus, compact systems that integrate the nitrogen and organic matter removal processes within a single unit (simultaneous nitrification and denitrification - SND) represent a suitable alternative to ensure access to sewage treatment in isolated communities.

Bench-scale investigations have shown the potential of applying the structured bed reactors subjected to recirculation and intermittent aeration (SBRRIA) to remove organic matter and nitrogen compounds from different wastewaters (Almeida et al., 2018; Barana et al., 2013; Correa et al., 2018; Moura et al., 2012, 2018; Santos et al., 2016, 2018; Silva et al., 2018; Wosiack et al., 2015). In the structured bed reactor, the biofilm grows adhered to a polyurethane (PU) foam that serves as a support material. A strong stratification of the substrate along with the foam depth allows the development of several bacterial 
communities (Moura et al., 2018; Silva et al., 2021). Therefore, aerobic heterotrophs, nitrifying and denitrifying bacteria can coexist in the biofilm. Intermittent aeration is used to balance the amount of oxygen available in the system and to ensure organic matter availability for denitrification over aerobic growth (Azevedo et al., 2021; Moura et al., 2018). In most bench-scale studies, high total-N and COD removal efficiencies were attained (Barana et al., 2013; Moura et al., 2012, 2018; Santos et al., 2016; Silva et al., 2021; Wosiack et al., 2015), resulting in final effluents compatible with disposal requirements established by Brazilian guidelines (CONAMA Resolutions No. 357/2005 and 430/2011).

It is well known that for the development of new researched processes the scale up is an essential challenge, especially concerning the proposal for a decentralized treatment. Therefore, the operation experiences achieved in this study aimed to present an alternative of sewage treatment for decentralized systems for isolated communities, such as residential condominiums and service stations on highways, due to the high efficiency.

\section{Methodology}

\subsection{Experimental setup}

The pilot-scale structured bed reactor (STBR) was constructed from fiberglass modules with a cylindrical shape. The cylindric had an internal diameter of $0.8 \mathrm{~m}$ (bottom area of $0.5 \mathrm{~m}^{2}$ ) and a total height of $2.0 \mathrm{~m}$ (Figure 1). Recirculation and feeding were performed using Hidrotech and ProMinent Beta pumps, respectively (Figure 1). Oxygen supply was carried out by a Schulz air compressor (BRAVO 6BR/60). The air compressor was connected to a circular air diffuser (Vagalhões, P-250 model) with $0.25 \mathrm{~m}$ diameter and a flow rate of $5.1 \mathrm{~m}^{3} \mathrm{O}_{2} \mathrm{~h}^{-1}$ (Figure 1). Moreover, the aeration system was connected to a timer and adjusted to obtain different aeration cycles.

Based on the reactor configuration adopted by Moura et al. (2012), 175 PU foams (0.03 m of square-base and 0.7-0.8 $\mathrm{m}$ of height) were used for biomass growth in the present study. The PU foams were vertically orientated inside the reactor (Figure 1) by their fixation in two circular stainless structures (diameter of $0.65 \mathrm{~m}$ and the structures' heights of 0.8 and $0.7 \mathrm{~m}$ ) (Figure 1). Furthermore, counterweights were required to submerge the stainless structures because of the high buoyancy force of PU foams. Since the fiberglass modules were adapted for the present study, there was no fixation point to hold the stainless structures. The counterweights consisted of fifteen PVC tubes with a diameter of $0.06 \mathrm{~m}$ filled with sand, of which six tubes were $0.8 \mathrm{~m}$ long and nine tubes were $0.5 \mathrm{~m}$ long. The PU foams' volume was approximately $0.23 \mathrm{~m}^{3}$ and the counterweights' volume was about $0.026 \mathrm{~m}^{3}$. The total volume and the working volume were $0.905 \mathrm{~m}^{3}$ and $0.642 \mathrm{~m}^{3}$, respectively, resulting in a bed porosity of $71 \%$. 
Figure 1. Experimental setup. 1. Influent and recirculation entry 2. Air entry. 3. Recirculation outline. 4. Effluent.
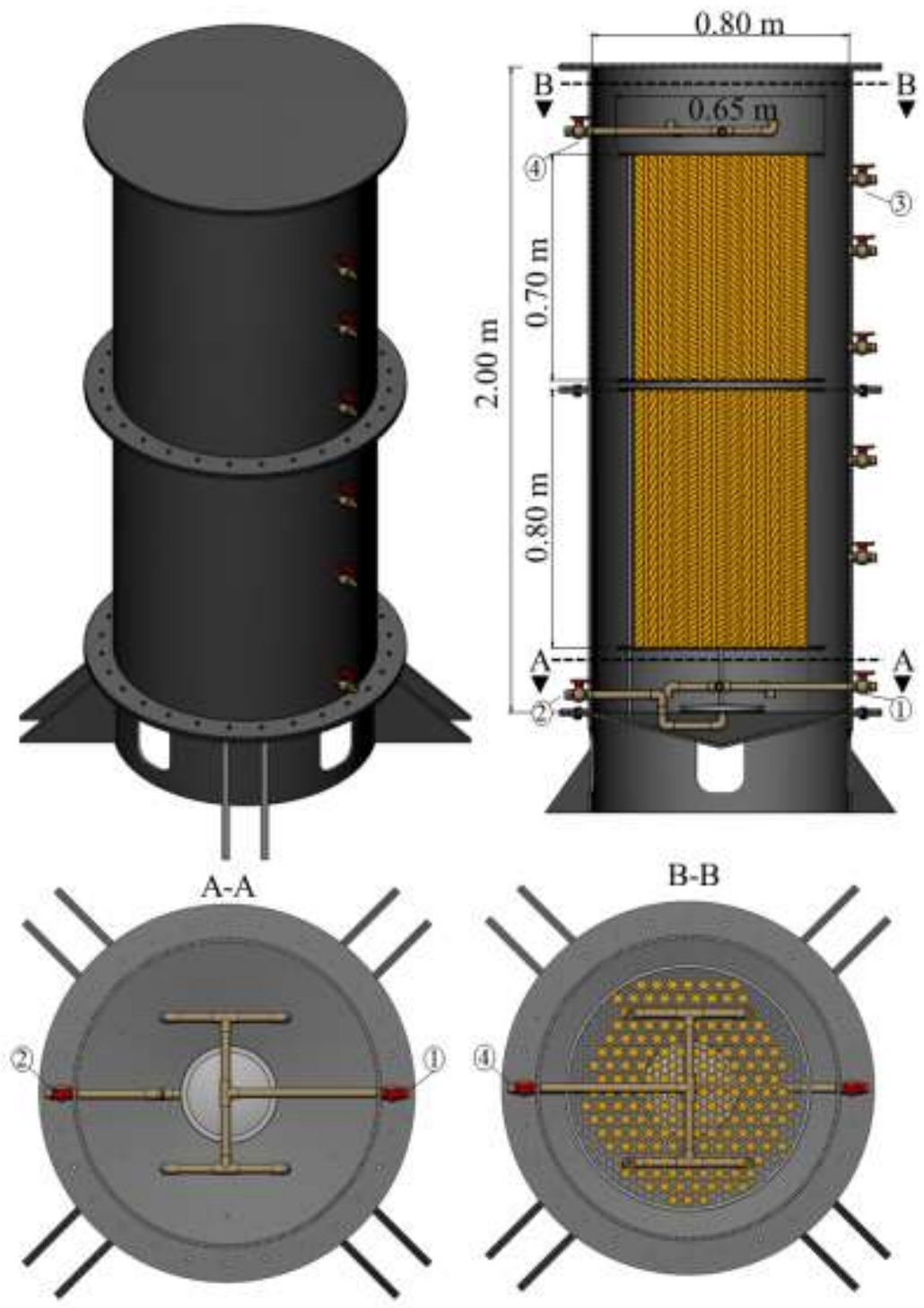

Source: Authors (2021).

\subsection{Inoculation and reactor start-up}

The reactor was inoculated with sludge from an activated sludge reactor with nitrifying activity (TSS of $1.37 \mathrm{~g} \mathrm{~L}^{-1}$ ). The STBR was filled with $0.150 \mathrm{~m}^{3}$ of sludge, $0.130 \mathrm{~m}^{3}$ of sewage and completed with tap water $\left(0.338 \mathrm{~m}^{3}\right)$. In the first eight days, $80 \mathrm{~L}$ of the liquid medium was exchanged daily by sewage. For the next seven weeks, the exchange was done weekly, and sodium bicarbonate $\left(\mathrm{NaHCO}_{3}\right)$ was added at a proportion of $7.14 \mathrm{mg} \mathrm{NaHCO}$ per $1 \mathrm{mg} \mathrm{NH}{ }_{4}^{+}-\mathrm{N}$. Finally, the system was continuously fed during 26 days with 48 hours of hydraulic retention time (HRT). At the end, COD removal and effluent ammonia concentration was $75 \%$ and $<5 \mathrm{mg} \mathrm{L}^{-1}$, respectively. During the whole start-up, continuous aeration was applied.

\subsection{Experimental procedure}

Sanitary sewage was gathered from a collector located in the neighborhood near Area 2 at the University of São Paulo (EESC/São Carlos, SP, Brazil). The sewage was stored in a reservoir (without temperature control), in which the solid particles were settled. The supernatant was pumped to the reactor (Figure 1) and had the following characteristics: chemical oxygen 
demand (COD) $\left(411 \pm 102 \mathrm{mg} \mathrm{L}^{-1}\right)$, total alkalinity $\left(180 \pm 22 \mathrm{mg} \mathrm{CaCO}_{3} \mathrm{~L}^{-1}\right), \mathrm{pH}(6.9 \pm 0.2)$, total Kjeldahl nitrogen (TKN) (35 $\left.\pm 9 \mathrm{mg} \mathrm{L}^{-1}\right)$, ammoniacal-N $\left(\mathrm{NH}_{4}{ }^{+}-\mathrm{N}\right)\left(25.8 \pm 6.1 \mathrm{mg} \mathrm{L}^{-1}\right)$, nitrate- $\mathrm{N}\left(\mathrm{NO}_{3}{ }^{-}-\mathrm{N}\right)\left(0.3 \pm 1.0 \mathrm{mg} \mathrm{L}^{-1}\right)$ and Total-N $(36.1 \pm 9.5 \mathrm{mg} \mathrm{L}$ $\left.{ }^{1}\right)$. Nitrite- $\mathrm{N}\left(\mathrm{NO}_{2}^{-}-\mathrm{N}\right)$ was not detected in the influent samples.

The reactor operation from this time onwards was chronologically divided into four stages, as shown in Table 1 . Different stages were tested by varying the HRT and in the last stage the aeration strategy, that started to be intermittent $(2 \mathrm{~h}$ of aeration and $1 \mathrm{~h}$ of non-aeration period). The temperature was not controlled, and it varied according to weather conditions recorded in the experimental period (average value of $22.5 \pm 5.0^{\circ} \mathrm{C}$ ).

Table 1. HRT, influent flow rate $(\mathrm{Q})$, aeration, recirculation ratio $\left(\mathrm{Q}_{\mathrm{R}} / \mathrm{Q}\right)$ and operation period for each operational stage of the pilot-scale STBR.

\begin{tabular}{llllll}
\hline Stages & $\begin{array}{l}\text { HRT } \\
(\mathbf{h})\end{array}$ & $\begin{array}{l}\mathbf{Q} \\
\left(\mathbf{L ~ h}^{-\mathbf{1}}\right)\end{array}$ & Aeration & $\mathbf{Q}_{\mathbf{R}} / \mathbf{Q}$ & $\begin{array}{l}\text { Operation period } \\
(\mathbf{d a y s})\end{array}$ \\
\hline 1 & 48.6 & 13.2 & Continuous & 15.1 & 28 \\
2 & 35.3 & 18.2 & Continuous & 11 & 36 \\
3 & 23.6 & 27.2 & Continuous & 7.3 & 32 \\
4 & 47.2 & 13.6 & Intermittent & 14.7 & 46 \\
\hline
\end{tabular}

Source: Authors (2021).

\subsection{Analytical methods}

Inlet and outlet samples were taken to monitor the system. According to American Public Health Association (APHA) et al. (2012), COD, pH, and TKN were measured. The dissolved oxygen (DO) concentration and temperature were obtained by using the Thermo Electron Orion $810 \mathrm{~A}+$ sensor. The $\mathrm{pH}$ was monitored by using a pH probe (UB-10 model, Denver Instrument potentiometer). Alkalinity was monitored by following (DiLallo \& Albertson, 1961)modified by (Ripley et al., 1986). NO ${ }_{2}^{-}-\mathrm{N}$ and $\mathrm{NO}_{3}{ }^{-}-\mathrm{N}$ were determined according to (Costa et al., 2018). Two methods were applied to quantify $\mathrm{NH}_{4}{ }^{+}-\mathrm{N}^{-}$the flow injection analysis (FIA) during Stages 1 and 2 and by Ion Chromatography in Stages 3 and 4. For the $\mathrm{NH}_{4}{ }^{+}-\mathrm{N}$ analysis, an IonPac CG12A column and IonPac AG23 Guard pre-column (4 mm $\times 50 \mathrm{~mm}$ ) were used at a temperature of $30^{\circ} \mathrm{C}$ and with an eluent sulfuric acid solution $(40 \mathrm{mM})$ at a similar flow rate of $1.0 \mathrm{~mL} \mathrm{~min}^{-1}$.

\section{Results and Discussion}

\subsection{COD and nitrogen removal}

COD removal efficiencies higher than $87 \%$ were achieved in all studied stages. The highest Total-N removal efficiency was achieved in Stage 4 and a low nitrification rate was observed at Stage 3. Characterization data of the influent and effluent in each experimental stage are presented in. Figures 2 and 3 display the influent and effluent profiles of nitrogenous compounds and the COD, nitrification, denitrification and Total-N removal efficiencies, respectively. 
Table 2. Summary of the influent and effluent physicochemical characterization and removal efficiencies of the pilot-scale STBR.

\begin{tabular}{|c|c|c|c|c|}
\hline Parameter & Stage 1 & Stage 2 & Stage 3 & Stage 4 \\
\hline \multicolumn{5}{|l|}{ Influent } \\
\hline $\mathrm{COD} / \mathrm{N}$ & 13.5 & 11.5 & 11.8 & 9.5 \\
\hline $\operatorname{COD}\left(\mathrm{mg} \mathrm{L}^{-1}\right)$ & $390 \pm 81$ & $421 \pm 66$ & $451 \pm 75$ & $384 \pm 83$ \\
\hline TKN (mg L-1) & $29 \pm 9$ & $36 \pm 8$ & $35 \pm 8$ & $41 \pm 9$ \\
\hline $\mathrm{NO}_{3}^{-}-\mathrm{N}\left(\mathrm{mg} \mathrm{L}^{-1}\right)$ & $0.7 \pm 1.8$ & - & - & $0.4 \pm 1.0$ \\
\hline $\mathrm{NO}_{2}^{-}-\mathrm{N}\left(\mathrm{mg} \mathrm{L}^{-1}\right)$ & $0.6 \pm 2.1$ & - & - & - \\
\hline Total alkalinity $\left(\mathrm{mg} \mathrm{CaCO}_{3} \mathrm{~L}^{-1}\right)$ & $195 \pm 16$ & $178 \pm 25$ & $190 \pm 20$ & $167 \pm 15$ \\
\hline $\mathrm{pH}$ & $6.8 \pm 0.1$ & $6.9 \pm 0.2$ & $7.0 \pm 0.3$ & $6.9 \pm 0.2$ \\
\hline Organic applied load (kgCOD m$\left.{ }^{-3} \mathrm{~d}^{-1}\right)$ & 0.192 & 0.286 & 0.459 & 0.195 \\
\hline Nitrogen applied load $\left(\mathrm{kgN} \mathrm{m}^{-3} \mathrm{~d}^{-1}\right)$ & 0.0143 & 0.0245 & 0.0356 & 0.0208 \\
\hline \multicolumn{5}{|l|}{ Effluent } \\
\hline $\mathrm{COD}\left(\mathrm{mg} \mathrm{L}^{-1}\right)$ & $38 \pm 14$ & $44 \pm 56$ & $58 \pm 18$ & $21 \pm 14$ \\
\hline TKN (mg L-1) & $2 \pm 3$ & $2 \pm 1$ & $19 \pm 7$ & $5 \pm 3$ \\
\hline $\mathrm{NO}_{3}^{-}-\mathrm{N}\left(\mathrm{mg} \mathrm{L}^{-1}\right)$ & $12 \pm 6$ & $12 \pm 4$ & $1 \pm 3$ & $5 \pm 3$ \\
\hline $\mathrm{NO}_{2}^{-}-\mathrm{N}\left(\mathrm{mg} \mathrm{L}^{-1}\right)$ & $0.3 \pm 0.6$ & $0.2 \pm 0.4$ & $0.1 \pm 0.3$ & $0.1 \pm 0.2$ \\
\hline Total- N (mg L-1 $)$ & $14.6 \pm 5.5$ & $14.4 \pm 3.3$ & $21.1 \pm 5.1$ & $11.1 \pm 3.1$ \\
\hline Total alkalinity $\left(\mathrm{mg} \mathrm{CaCO}_{3} \mathrm{~L}^{-1}\right)$ & $56 \pm 42$ & $49 \pm 18$ & $172 \pm 28$ & $53 \pm 17$ \\
\hline $\mathrm{pH}$ & $6.9 \pm 0.5$ & $6.9 \pm 0.3$ & $7.4 \pm 0.3$ & $7.2 \pm 0.2$ \\
\hline Organic removed load $\left(\mathrm{kgCOD} \mathrm{m} \mathrm{m}^{-3} \mathrm{~d}^{-1}\right)$ & 0.174 & 0.256 & 0.400 & 0.184 \\
\hline Total-N removed load $\left(\mathrm{kgN} \mathrm{m}^{-3} \mathrm{~d}^{-1}\right)$ & 0.0073 & 0.0145 & 0.0153 & 0.0150 \\
\hline
\end{tabular}

(-) Values below the detection limit.

Source: Authors (2021).

Figure 2. Boxplot profiles and Kruskal-Wallis and Wilcoxon statistical tests (p-value <0,05) of COD removal (a), nitrification (b), denitrification (c) and Total-N removal (d) efficiencies for the studied stages.

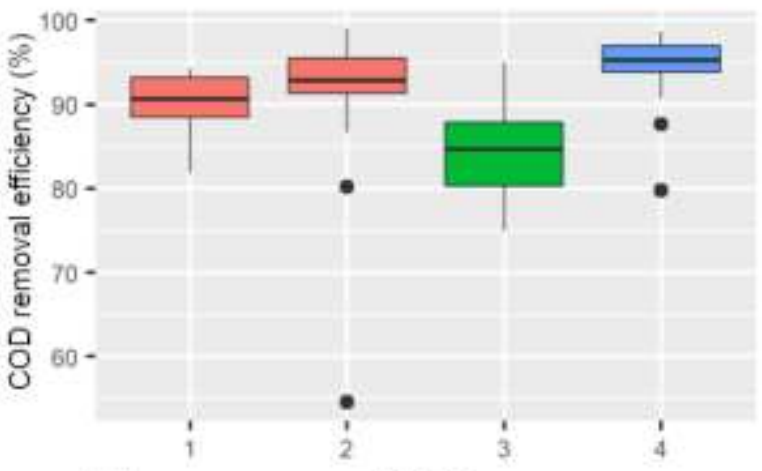

(a)

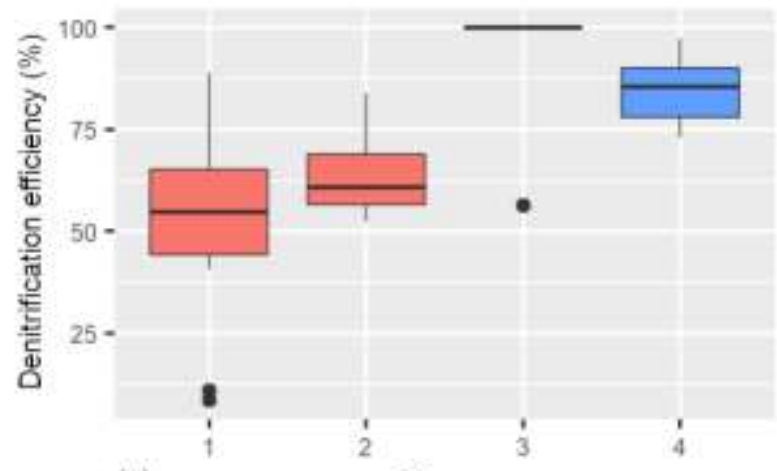

(c)

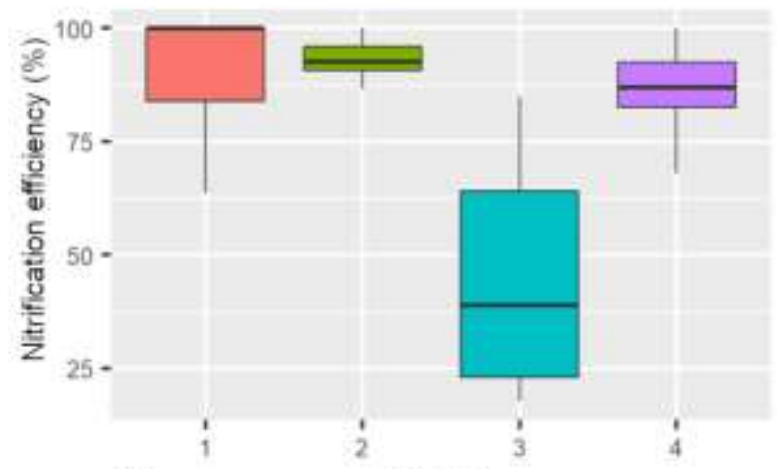

(b)

Stages

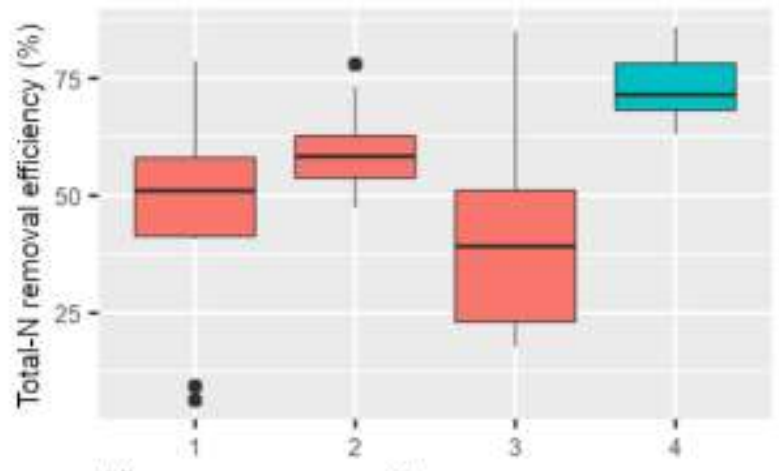

(d)

Source: Authors (2021). 
As seen in Figure 2a, the highest COD removal efficiency was obtained in Stage 4, with an average value of $94 \pm 5 \%$. The lowest COD removal efficiency was observed in Stage 3 (84 $\pm 6 \%$ ) (Figure 2A). Moreover, the low dispersion of the COD removal efficiency indicates the high system's stability. This trend is similar to observations from previous studies that operated bench-scale SBRRIAs to treat sewage. Moura et al. (2012) obtained COD removal efficiencies larger than $85 \%$ even when the HRT in the SBRRIA was reduced from 12 to $8 \mathrm{~h}$. COD removal efficiencies were approximately $90 \%$ when a SBRRIA was operated to treat domestic sewage and the impacts of different operational parameters on SND were evaluated (Moura et al., 2018).

By comparing the disposal COD concentration established by Brazilian guidelines for effluent discharge (below $40 \mathrm{mg}$ $\mathrm{L}^{-1}$ ) with the effluent COD concentrations reached at the pilot-scale (Table 2), it can be seen that this alternative is suitable for organic matter removal from sanitary sewage. The results obtained in the present study demonstrate the configuration robustness of removing organic matter on a pilot-scale. Although the pilot-scale system was operated with a HRT superior to previous studies, it is important to highlight that at this study the reactor working volume was approximately 100 times bigger than the values applied in the majority of the bench-scale experiences (Table 4). Some issues related to scaling up, such as air dispersion in the liquid medium, liquid distribution at the reactor base and the automation of the aeration system still need to be improved, in order to consolidate STBR into a viable technology for decentralized SND unit. Eckenfelder et al. (1972) observed that the complexity and inherent variability of a prototype performance to wastewater treatment interfere in the lack of information regarding the scale-up, such as the influence of bacterial growth kinetics, the effect of turbulence and the fluid dynamics of nonideal reactors. The low turbulence in the system, mentioned by the authors, may be related to the degree of mixing far from an optimal level (Eckenfelder et al., 1972). Consequently, some conditions, such as the air-flow rate, the type of air injector, variation of temperature, mean residence time and tank geometry, affect the mixing (Eckenfelder et al., 1972).

In Stages 1 and 2, the nitrification efficiencies were higher than 90\% (Figure 2b), even with the HRT reduction from 48.6 to $35.3 \mathrm{~h}$. In Stage 3, when HRT was reduced to $23.6 \mathrm{~h}$ a drop in the nitrification efficiency was observed (average value of $45 \%$ ). In this condition, the HRT reduction resulted in the increase in 1.5-fold at both organic and nitrogen applied loads, as presented in Table 2. Most likely the oxygen availability in the liquid medium was the limiting factor for the activity of nitrifying community. Although the air flow applied to the STBR was levelled out at $5.1 \mathrm{~m}^{3}$ air $\mathrm{h}^{-1}$ during the whole experimental period, the oxygen demand increased by 1.7-fold at Stage 3 (

) and the recirculation ratio was the lowest (Table 1), which decreased the dilution of sewage. Theoretically, the airflow capacity of the diffuser would be sufficient to supply the oxygen for nitrification and COD oxidation in all experimental stages. However, the diffuser installation did not fully follow the manufacturer's recommendation regarding the liquid height and the influence area. This issue and other design challenges will be discussed further.

The poor air distribution may have contributed to the DO deficit in the liquid medium in Stage $3\left(1.0 \pm 0.6 \mathrm{mgO}_{2} \mathrm{~L}^{-1}\right)$, resulting in low nitrification and Total-N removal performances. The nitrification may be restrained in DO levels varying between 0.5 and $2.5 \mathrm{mgO}_{2} \mathrm{~L}^{-1}$ (EPA, 1993), and Water Environment Federation (WEF) et al. (2006) recommend values wider than $2.0 \mathrm{mgO}_{2} \mathrm{~L}^{-1}$ for full nitrification in WWTPs. Oxygen as a limiting factor for nitrification was also observed in moving bed biofilm reactors (MBBRs) operated on bench- and pilot-scales (Hem et al., 1994) and in a SBRRIA treating sewage (Azevedo et al., 2021). In both studies, the nitrification loss was related to the DO consumption by the heterotrophs, which consequently suppressed the activity of the nitrifying bacteria (Azevedo et al., 2021; Hem et al., 1994). In fact, the average DO concentration in Stage 3 was the minimal $\left(1.0 \pm 0.6 \mathrm{mg} \mathrm{O}_{2} \mathrm{~L}^{-1}\right)$ recorded by the DO sensor (Table 3). 
Table 3. Theoretical oxygen demand for organic matter (COD) oxidation, nitrification and denitrification bioprocesses

\begin{tabular}{|c|c|c|c|c|c|c|c|c|}
\hline Stages & $\begin{array}{l}\text { DO } \\
\left(\mathrm{mg} \mathrm{O}_{2} \mathrm{~L}^{-1}\right)\end{array}$ & $\begin{array}{l}\text { Flow } \\
\left(\mathrm{m}^{3} \text { air d } \mathbf{d}^{-1}\right)\end{array}$ & $\begin{array}{l}\mathrm{O}_{2} \quad \text { demand } \\
\text { nitrification } \\
\left(\mathrm{gO}_{2} \mathrm{~d}^{-1}\right)\end{array}$ & for & $\begin{array}{l}\mathrm{O}_{2} \quad \text { demand for } \\
\text { oxidation } \\
\left(\mathrm{gO}_{2} \mathrm{~d}^{-1}\right)^{*}\end{array}$ & COD & $\begin{array}{l}\mathrm{O}_{2} \\
\text { demand } \\
\left(\mathrm{gO}_{2} \mathrm{~d}^{-1}\right)\end{array}$ & total \\
\hline 1 & $3.0 \pm 0.8$ & 0.32 & 38.06 & & 112.48 & & 151.49 & \\
\hline 2 & $2.5 \pm 0.3$ & 0.44 & 66.59 & & 158.70 & & 226.38 & \\
\hline 3 & $1.0 \pm 0.6$ & 0.65 & 49.82 & & 327.11 & & 377.58 & \\
\hline 4 & $2.8 \pm 0.5$ & 0.33 & 53.76 & & 116.63 & & 171.30 & \\
\hline
\end{tabular}

* The demand for organic matter to reduce nitrate (denitrification) has already been discounted based on the average efficiency of each stage.

Source: Authors (2021).

In Stage 4, the nitrification efficiency increased to $86 \pm 7 \%$ even with intermittent aeration (Figure 2b). The HRT raised from 23.6 (Stage 3) to $47.2 \mathrm{~h}$ (Stage 4), which reflected in the reduction in both organic and nitrogen applied loads. Consequently, the applied air flow proved to be adequate to ensure both nitrification and COD removal (Figures 2A and 2B). Indeed, the intermittent aeration could also be an important factor that helps the Total-N removal metabolism over the heterotrophic oxidation in biofilm-based reactors. Horntvedt et al. (1998) improved the denitrification and the Total-N removal by oscillating DO concentration, from 0 to $2.0 \mathrm{mg} \mathrm{O}_{2} \mathrm{~L}^{-1}$. The DO oscillation reduced the growth of an aerobic heterotrophic culture by $16 \%$ when compared to the behavior achieved at $1 \mathrm{mg} \mathrm{O}_{2} \mathrm{~L}^{-1}$ (Horntvedt et al., 1998). The authors found that nitrogen removal increased by $30 \%$ compared to the constant DO situation in a full-scale compact moving bed biofilm wastewater treatment plant (Horntvedt et al., 1998). Furthermore, at Stage 4, the DO increased to the same levels observed at Stages 1 and 2 even with the intermittent aeration (Table 3), indicating that the DO levels for SND in the present arrangement could be different from that reported in previous studies.

The highest denitrification efficiency was obtained at Stage 3 with the minor DO concentration in the medium (1.0 \pm $0.6 \mathrm{mg} \mathrm{O}_{2} \mathrm{~L}^{-1}$ ). Denitrification occurs, preferably at DO concentrations below $1 \mathrm{mg} \mathrm{O}_{2} \mathrm{~L}^{-1}$ (Surampalli et al., 1997). A high average denitrification value of $85 \%$ was observed in Stage 4. Thus, adding intermittent aeration promoted an increase in denitrification efficiency by about 30\% (comparing Stages 1 and 4). This probably occurred because of the alternation between low and high DO concentrations. In anoxic periods, the activity of aerobic heterotrophic bacteria may have decreased, leaving electron donors for the nitrate reduction (denitrification). On the other hand, at high DO level, nitrification was favored. Other studies already observed an improvement in denitrification by using intermittent aeration systems (Santos et al., 2016; Yang \& Yang, 2011).

The highest Total-N removal efficiency was achieved at Stage 4 (74 7\%) with a low data dispersion (Figure 2D), which suggests the system stability for Total-N biodegradation. This result approaches previous studies that treated synthetic sewage (Moura et al., 2012) and raw sewage (Moura et al., 2018) in bench-scale STBRs, highlighting that the highest removal rate reported was $88.1 \%$ (Table 4). A balanced and high efficiency of denitrification and nitrification was observed at Stage 4 (Figure 2), which is important since the equilibrium between nitrification and denitrification processes is essential in SND systems (Damianovic et al., 2018). Conversely, Stages 1 and 2 gained greater nitrification efficiencies than in Stage 4 (Figure 2b), and the denitrification efficiency was higher in Stage 3 than Stage 4 (Figure 2c). Therefore, it can be concluded that the nitrification and denitrification efficiencies should not be analyzed in isolation, since the optimum values of each of these parameters may not represent the best operational condition to achieve high Total-N removed loads. 


\subsection{Operational design challenges associated with the scale-up}

The Total-N removal efficiency and the applied HRT indicate a lower performance of the pilot-scale reactor when compared to the bench-scale studies reported in the literature (Table 4). As aforementioned, the nitrification efficiency and DO decreased at Stage 3 due to the higher oxygen demand for COD oxidation and nitrification, with an HRT of $23.6 \mathrm{~h}$ (Table 4). Considering that a bench-scale reactor obtained a Total-N removal efficiency of 79\% with HRT of $12 \mathrm{~h}$ treating sanitary sewage (Moura et al., 2018), it suggests that the HRT could be lower in the pilot-scale reactor if an adequate amount of oxygen was delivered to the system. Nevertheless, the low DO at Stage 3 (Table 3) indicated restrained oxygen transfer. As can be seen in Figure 1, one single air diffuser was installed in the pilot-scale reactor due to a limitation of space at the base despite the manufacturer's recommendation to install more diffusers. Most likely, the oxygen concentrations in the STBR were not homogenous with the bed because of poor air distribution. At Stages 1 and 2, the longer HRT helped aeration in the STBR, as higher HRT may minimize adjustments in oxygen transfer systems, promoted by hydraulic equalization (Daigger \& Littleton, 2014). The recirculation rate at Stages 1 and 2 also contributed to carrying out the air diffusion since it promotes hydraulic mixing of reactor volume ( $\mathrm{Qr}>11$, Table 1). Conversely, at Stage 3, the recirculation rate was lower (due to the pump specification), and it was not enough to improve air diffusion. In fact, during the entire operational period, the recirculation pump frequently shut down due to power failure which could also negatively affect the air diffusion in the STBR. 
Table 4. Maximum organic and nitrogenous matter removal in STBR reactors applied to treat different wastewaters.

\begin{tabular}{|c|c|c|c|c|c|c|c|}
\hline Reference & Wastewater & $\begin{array}{c}\text { Reactor scale/ } \\
\text { Working volume (L) }\end{array}$ & $\begin{array}{c}\text { HRT } \\
\text { (hours) }\end{array}$ & $\begin{array}{l}\text { COD removal } \\
\text { efficiency }(\%)\end{array}$ & $\begin{array}{l}\text { Nitrification } \\
\text { efficiency }(\%)\end{array}$ & $\begin{array}{l}\text { Denitrification } \\
\text { efficiency }(\%)\end{array}$ & $\begin{array}{c}\text { Total-N removal } \\
\text { efficiency }(\%)\end{array}$ \\
\hline (Moura et al., 2012) & Synthetic sewage & $\begin{array}{l}\text { Bench-scale } \\
6.1 \mathrm{~L}\end{array}$ & 12 & 89 & 88 & 80.6 & 82 \\
\hline (Barana et al., 2013) & $\begin{array}{l}\text { Synthetic UASB effluent treating poultry } \\
\text { slaughterhouse wastewater }\end{array}$ & $\begin{array}{l}\text { Bench-scale } \\
\text { NA }\end{array}$ & 24 & 95 & 96 & NA & 62 \\
\hline $\begin{array}{l}\text { (Wosiack et al., } \\
\text { 2015) }\end{array}$ & Animal food plant effluent & $\begin{array}{l}\text { Bench-scale } \\
\text { NA }\end{array}$ & NA & 80 & 99.1 & 88.9 & 88.1 \\
\hline (Santos et al., 2016) & Synthetic substrate & Bench-scale & 11.2 & 96 & 85 & 67 & 81.5 \\
\hline (Silva et al., 2018) & UASB effluent treating sewage & $\begin{array}{l}\text { Bench-scale } \\
\quad 9.6 \mathrm{~L}\end{array}$ & 12 & 82 & 82 & NA & 29 \\
\hline (Almeida et al., 2018) & UASB effluent & $\begin{array}{l}\text { Bench-scale } \\
6.1 \mathrm{~L}\end{array}$ & 24 & 63 & 80 & 58 & 48 \\
\hline (Moura et al., 2018) & Sanitary sewage & $\begin{array}{l}\text { Bench-scale } \\
6.1 \mathrm{~L}\end{array}$ & 8 & 89 & 91.1 & 85.6 & 79 \\
\hline (Correa et al., 2018) & Sanitary sewage & Bench-scale & 16 & 94 & 86 & 74 & 80 \\
\hline $\begin{array}{l}\text { (Azevedo et al., } \\
\text { 2021) }\end{array}$ & Sanitary sewage & $\begin{array}{l}\text { Bench-scale } \\
9.4 \mathrm{~L}\end{array}$ & 16 & 94 & 80 & 82 & 67 \\
\hline (Santos et al., 2018) & $\begin{array}{l}\text { UASB effluent treating a saline sewage } \\
\qquad(0.47 \% \text { of salinity })\end{array}$ & $\begin{array}{l}\text { Bench-scale } \\
9.6 \mathrm{~L}\end{array}$ & 18 & 100 & 59 & 92 & 55 \\
\hline (Macêdo et al., 2019) & $\begin{array}{l}\text { Multi-electrolytes saline sewage } \\
\qquad(8 \% \text { of salinity) }\end{array}$ & $\begin{array}{c}\text { Bench-scale } \\
1.3 \mathrm{~L}\end{array}$ & 12 & 97.2 & 95.9 & 68.4 & 65.8 \\
\hline (Oliveira et al., 2020) & Synthetic sewage & Bench-scale & 13.6 & 80 & NA & NA & $25-80$ \\
\hline This study & Sanitary sewage & Pilot-scale & 47.2 & 94 & 86 & 85 & 74 \\
\hline
\end{tabular}

NA: data not available.

Source: Authors (2021). 
Nevertheless, the strategy of combining the limited area of air diffusion and recirculation did not achieve a balance of nitrification and denitrification as seen at Stages 1, 2, and 3. Daigger and Littleton (2014) described that some macro and microenvironments are essential for the SND process such as oxygen transfer and DO level conditions; biofilm thickness in the PU foam and the discovery of microorganisms using new biochemical pathways. At HRT higher than $35 \mathrm{~h}$ (Stages 1 and 2), the nitrification was favored (Figure 2). On the other hand, at HRT of $23.6 \mathrm{~h}$ (Stage 3) the denitrification was favored (Figure 2) suggesting a limited capacity of oxygen transfer as aforementioned. Although the DO in the liquid medium was similar to the values for the SND occurrence reported by Horntvedt et al. (1998), the hypothesis of recirculation dependence for air diffusion could explain the low nitrogen removal at Stage 3. A better balance of nitrification and denitrification was obtained at Stage 4 with intermittent aeration. At Stage 4, a higher HRT associated with the recirculation improved the oxygen mass transfer even with intermittent aeration, resulting in an adequate macroenvironment for the SND process.

The diffuser submergence depth and bubble size are important aspects to ensure an adequate oxygen transfer in the liquid. As nitrifiers are autotrophic and have low growth velocity when compared with aerobic heterotrophs, this bacteria group is strongly affected by the lack of DO. Codas et al. (2002) evaluated the standard oxygen transference efficiency (SOTE) in bioreactors in different conditions, such as: with and without material support and (ii) with different reactor heights. By using a coarse-bubble diffuser and attached biomass, the SOTE was improved from $8 \%$ to $16 \%$ with the height rise (from 2.6 to $4.4 \mathrm{~m}$ ) (Codas et al., 2002). Codas et al. (2002) reported a high value of SOTE using a coarse-bubble diffuser (17\%) instead of a fine bubble diffuser (12\%) at an airflow of $2.9 \mathrm{~m}^{3} \mathrm{~m}^{-3}$ reactor $^{-1}$. In the present study, a fine bubble diffuser was used, and the reactor height was $2.0 \mathrm{~m}$ which hindered SOTE. Additionally, special attention should be highlighted to the structure for the fixation of PU foams adopted in the pilot-scale investigation. Beside the buoyancy force issue, which would be easily solved with the previous installation of fixation points in the fiberglass modules, the choice of the structure material should resist under contact with sewage. In the present study, despite the stainless structure, at the end of the experiment the welds of the structure were separated due to the contact with sewage.

The setup has a limited capacity of oxygen transfer because of the number of diffusers installed beside the lower SOTE due to the height of the reactor. Most likely, with more diffusers, the SND process could be carried out at lower HRT. Particularly, the issues of oxygen transfer could be mitigated by effluent recirculation and high HRT. For the present study, recirculation was the key feature to ensure the effluent mixture and support the oxygen transfer. Conversely, Oliveira et al. (2020) observed that aeration, as a sole operational parameter, ensured complete mixing in a bench-scale STBR. This fact highlights the recommendation of adequate disposal of air diffusers. Despite the fact that recirculation could be dispensable in a reactor with a sufficient number of diffusers as observed by Oliveira et al. (2020), the present study revealed that the maintenance of the recirculation is appropriate to deal with eventual issues of oxygen transfer. We also observed that the intermittent aeration was a suitable strategy to carry out SND while the constant aeration was hindered by issues of oxygen transfer. However, the full aeration strategy should not be discarded. Therefore, an adequate setup of air diffusers and recycling flow (only when the air diffusion is not enough by the diffusers) could ensure the oxygen demand for organic matter and nitrogen removal, carrying out the SND process.

\section{Conclusion}

The concomitant removal of both organic matter and nitrogen from sanitary sewage was achieved in a pilot-scale STBR subjected to different HRTs and aeration strategies. The setup of air diffusion and recirculation of effluent was crucial for the results obtained. Recirculation helped the oxygen transfer when the number of diffusers was not enough. Nevertheless, a macroenvironment favorable for the SND process is hindered at constant aeration when using recirculation of effluent to help oxygen transfer. The intermittent aeration strategy was more effective to balance nitrification and denitrification when using recirculation 
to help oxygen transfer. Despite the difficulties presented, this reactor configuration is an interesting alternative for sanitary sewage treatment for isolated communities, as well as other areas which demand compact units.

For future research work, some suggestions are highlighted for the STBR to achieve better performance and become a technology, such as sizing the aeration system, testing the bed porosity and foam size, evaluating intermittent aeration conditions as well as an economic feasibility study.

\section{Acknowledgments}

We would like the acknowledge the financial support from the FAPESP (São Paulo Research Foundation) (Grants \#2012-2/131343 and \#2015/06246-7] and CNPq (Conselho Nacional de Desenvolvimento Científico e Tecnológico).

\section{References}

Almeida, R. G. B. de, Santos, C. E. D., Lüders, T. C., del Nery, V., Leal, C. D., Pereira, A. D., Araújo, J. C., Davenport, R. J., Barana, A. C., Lopes, D. D., \& Damianovic, M. H. R. Z. (2018). Nitrogen removal by simultaneous partial nitrification, anammox and denitrification (SNAD) in a structured-bed reactor treating animal feed processing wastewater: Inhibitory effects and bacterial community. International Biodeterioration \& Biodegradation, 133 . https://doi.org/10.1016/j.ibiod.2018.06.019

American Public Health Association (APHA), American Water Works Association (AWWA), \& Water Environment Federation (WEF). (2012). Standard Methods for the Examination of Water and Wastewater (Eugene W. Rice, Rodger B. Baird, Andrew D. Eaton, \& Lenore S. Ciesceri, Eds.; 22nd ed). American Public Health Association.

Azevedo, C. S., Correa, C. Z., Lopes, D. D., Pescim, R. R., Prates, K. V. M. C., \& Barana, A. C. (2021). Aeration and non-aeration cycles (AE/NA) time: influence in combined organic matter and nitrogen removal and features of biofilm. Environmental Technology. https://doi.org/10.1080/09593330.2021.1882583

Barana, A. C., Lopes, D. D., Martins, T. H., Pozzi, E., Damianovic, M. H. R. Z., del Nery, V., \& Foresti, E. (2013). Nitrogen and organic matter removal in an intermittently aerated fixed-bed reactor for post-treatment of anaerobic effluent from a slaughterhouse wastewater treatment plant. Journal of Environmental Chemical Engineering, 1(3). https://doi.org/10.1016/j.jece.2013.06.015

Codas, B. V. B., Schmidell, W., \& Alem, P. (2002). Avaliação da transferência de oxigênio em um biorreator aerado submerso com enchimento. XXVIII Congreso Interamericano de Ingeniería Sanitaria y Ambiental, 1-8.

Correa, C. Z., Prates, K. V. M. C., de Oliveira, E. F., Lopes, D. D., \& Barana, A. C. (2018). Nitrification/denitrification of real municipal wastewater in an intermittently aerated structured bed reactor. Journal of Water Process Engineering, 23. https://doi.org/10.1016/j.jwpe.2018.03.013

Costa, R. B., Camiloti, P. R., Sabatini, C. A., Santos, C. E. D., Lima Gomes, P. C. F., \& Adorno, M. Â. T. (2018). Matrix Effect Assessment of an Ion Chromatographic Method to Determine Inorganic Anions in Wastewater. Water, Air, and Soil Pollution, 229(7). https://doi.org/10.1007/s11270-018-3863-5

Daigger, G. T., \& Littleton, H. X. (2014). Simultaneous Biological Nutrient Removal: A State-of-the-Art Review. Water Environment Research, 86(3), 245257. https://doi.org/10.2175/106143013x13736496908555

Damianovic, M. H. R. Z., Santos, C. E. D., Martín, M. A. M., Fdz-Polanco, M., Foresti, E., Fdz-Polanco, F., \& García-Encina, P. A. (2018). Specific Activity Bioassays as Tools to Evaluate Combined Nitrogen and Organic Matter Removal in SND Systems. Environmental Engineering Science, 35(9). https://doi.org/10.1089/ees.2017.0418

DiLallo, R., \& Albertson, O. E. (1961). Volatile acids by direct titration. Journal Water Pollution Control Federation, 33(4), 356-365.

Eckenfelder, W. W., Goodman, B. L., \& Englande, A. J. (1972). Scale-up of biological wastewater treatment reactors. Advances in Biochemical Engineering, Volume 2, 145-180. https://doi.org/10.1007/bfb0006668

EPA. (1993). Nitrogen Control. U. S. Environmental Protection Agency.

Gikas, P., \& Tchobanoglous, G. (2009). The role of satellite and decentralized strategies in water resources management. Journal of Environmental Management, 90(1), 144-152. https://doi.org/10.1016/j.jenvman.2007.08.016

Hem, L., Rusten, B., \& Ødegaard, H. (1994). Nitrification in a moving bed biofilm reactor. Water Research, 28(6), 1425-1433. https://doi.org/10.1016/00431354(94)90310-7

Horntvedt, B. R., Rambekk, M., \& Bakke, R. (1998). Oscillating conditions for influencing the composition of mixed biological cultures. Water Science Technology, 37(4-5), 259-262.

IBGE. (2015). Pesquisa nacional por amostra de domicílios: síntese de indicadores 2013 (2nd ed). IBGE.

Macêdo, W. V., Santos, C. E. D., Guerrero, R. de B. S., Sakamoto, I. K., Amorim, E. L. C. de, Azevedo, E. B., \& Damianovic, M. H. R. Z. (2019). Establishing simultaneous nitrification and denitrification under continuous aeration for the treatment of multi-electrolytes saline wastewater. Bioresource Technology, 288 . https://doi.org/10.1016/j.biortech.2019.121529 
Moura, R. B., Damianovic, M. H. R. Z., \& Foresti, E. (2012). Nitrogen and carbon removal from synthetic wastewater in a vertical structured-bed reactor under intermittent aeration. Journal of Environmental Management, 98. https://doi.org/10.1016/j.jenvman.2012.01.009

Moura, R. B., Santos, C. E. D., Okada, D. Y., Martins, T. H., Ferraz Júnior, A. D. N., Damianovic, M. H. R. Z., \& Foresti, E. (2018). Carbon-nitrogen removal in a structured-bed reactor (SBRRIA) treating sewage: Operating conditions and metabolic perspectives. Journal of Environmental Management, 224. https://doi.org/10.1016/j.jenvman.2018.07.014

Moussavi, G., Kazembeigi, F., \& Farzadkia, M. (2010). Performance of a pilot scale up-flow septic tank for on-site decentralized treatment of residential wastewater. Process Safety and Environmental Protection, 88(1), 47-52. https://doi.org/10.1016/j.psep.2009.10.001

Oliveira, E. P., Souza, T. S. O., Okada, D. Y., Damasceno, L. H. S., \& Moura, R. B. (2020). Effect of air flow, intermittent aeration time and recirculation ratio in the hydrodynamic behavior of a structured bed reactor. Chemical Engineering Journal, 394(March), 124988. https://doi.org/10.1016/j.cej.2020.124988

Ripley, L. E., Boyle, W. C., \& Converse, J. C. (1986). Improved alkalimetric monitoring for anaerobic digestion of high-strength wastes. Journal of the Water Pollution Control Federation, 58(5), 406-411.

Santiago-Díaz, Á. L., García-Albortante, J., \& Salazar-Peláez, M. L. (2019). UASB-septic tank as an alternative for decentralized wastewater treatment in Mexico. Environmental Technology (United Kingdom), 40(14), 1780-1792. https://doi.org/10.1080/09593330.2018.1430170

Santos, C. E. D., Moura, R. B., Damianovic, M. H. R. Z., \& Foresti, E. (2016). Influence of COD/N ratio and carbon source on nitrogen removal in a structuredbed reactor subjected to recirculation and intermittent aeration (SBRRIA). Journal of Environmental Management, 166, 519-524. https://doi.org/10.1016/j.jenvman.2015.10.054

Santos, C. E. D., Guerrero, R. de B. S., Godoi, L. A. G., Foresti, E., \& Damianovic, M. H. R. Z. (2018). Dynamics of the nitrification and sulfide-driven autotrophic denitrification processes in a single reactor using oxidation-reduction potential as an indicator of the process effectiveness. Journal of Chemical Technology \& Biotechnology, 93(12). https://doi.org/10.1002/jctb.5707

Silva, B. G., Damianovic, M. H. R. Z., \& Foresti, E. (2018). Effects of intermittent aeration periods on a structured-bed reactor continuously fed on the posttreatment of sewage anaerobic effluent. Bioprocess and Biosystems Engineering, 41(8). https://doi.org/10.1007/s00449-018-1940-1

Silva, B. G., Oliveira, J. M. S., Damianovic, M. H. R. Z., \& Foresti, E. (2021). Foam aerated biofilm reactor: a novel counter-diffusional process for COD and nitrogen removal from low COD/N effluents. Environmental Technology. https://doi.org/10.1080/09593330.2021.1893830

Singh, N. K., Kazmi, A. A., \& Starkl, M. (2015). A review on full-scale decentralized wastewater treatment systems: Techno-economical approach. Water Science and Technology, 71(4), 468-478. https://doi.org/10.2166/wst.2014.413

Sistema Nacional de Informações sobre Saneamento. (2019). 24 Diagnóstico dos Serviços de Água e Esgoto. http://www.snis.gov.br/downloads/diagnosticos/ae/2018/Diagnostico_AE2018.pdf

Surampalli, R. Y., Tyagi, R. D., Scheible, O. K., \& Heidman, J. a. (1997). Nitrification, denitrification and phosphorus removal in sequential batch reactors. Bioresource Technology, 61(2), 151-157. https://doi.org/10.1016/S0960-8524(97)00034-5

von Sperling, M. (2016). Urban wastewater treatment in Brazil. Inter-American Development Bank, August, 27. www.iadb.org

Water Environment Federation (WEF), American Society of Civil Enginneers (ASCE), \& Environmental and Water Resource Institute (EWRI). (2006). Biological nutrient removal (BNR) operation in wastewater treatment plants: WEF Manual of Practice No. 30 (No. 109). McGraw-Hill Education.

Wosiack, P. A., Lopes, D. D., Damianovic, M. H. R. Z., Foresti, E., Granato, D., \& Barana, A. C. (2015). Removal of COD and nitrogen from animal food plant wastewater in an intermittently-aerated structured-bed reactor. Journal of Environmental Management, 154. https://doi.org/10.1016/j.jenvman.2015.02.026

Yang, S., \& Yang, F. (2011). Nitrogen removal via short-cut simultaneous nitrification and denitrification in an intermittently aerated moving bed membrane bioreactor. Journal of Hazardous Materials, 195, 318-323. https://doi.org/10.1016/j.jhazmat.2011.08.045 